\title{
Pengaruh Tekanan Blower pada Proses Pembakaran Sampah Medis Menggunakan Insinerator Statis terhadap Kualitas Abu
}

\author{
Pungut $^{1}$, Muhammad Al Kholif ${ }^{2 *}$, Audi Arga Perwira Nagariagam Sugianto ${ }^{3}$ \\ 1,2,3 Program Studi Teknik Lingkungan, Fakultas Teknik Universitas PGRI Adi Buana Surabaya \\ Koresponden email: alkholif87@ unipasby.ac.id
}

Diterima: 7 November 2021

Disetujui: 26 Desember 2021

\begin{abstract}
Medical waste generated from the activities of hospitals or other health facilities is very dangerous and can cause health problems for humans. One way of processing medical waste is by using an incinerator. This study aims to determine the effect of blower pressure on the medical waste incineration process on the levels of Cadmium (Cd), Chromium VI $\left(\mathrm{Cr}^{+6}\right)$, and Lead $(\mathrm{Pb})$ in the ash residue based on the TCLP test. The method applied is to weigh $300 \mathrm{~kg}$ of medical waste and then burn it in an incinerator with a blower pressure variation of 10 and $30 \mathrm{mbar}$ at an optimal temperature of $1,200{ }^{\circ} \mathrm{C}$. The results showed that the best TCLP test with a blower pressure of $10 \mathrm{mbar}$ was $\mathrm{Cd}$ of $0.411 \mathrm{mg} / \mathrm{L}$ in experiment $2, \mathrm{Cr}^{+6}$ of $0.143 \mathrm{mg} / \mathrm{L}$ in experiment 2 , and $\mathrm{Pb}$ of $59.4 \mathrm{mg} / \mathrm{L}$ in experiment 3. Meanwhile, the results of the best TCLP test in Experiment 3 with a blower pressure of $30 \mathrm{mbar}$ are $\mathrm{Cd}$ of $0.34 \mathrm{mg} / \mathrm{L}, \mathrm{Cr}^{+6}$ of $0.098 \mathrm{mg} / \mathrm{L}$, and $\mathrm{Pb}$ of $42.2 \mathrm{mg} / \mathrm{L}$. The results showed that the levels of $\mathrm{Cd}$ and $\mathrm{Cr}+6$ had met the environmental quality standards, while the $\mathrm{Pb}$ levels had not met the required environmental quality standards.
\end{abstract}

Keywords: blower pressure, incineration, medical waste, TCLP test, hospital

\begin{abstract}
Abstrak
Limbah medis yang dihasilkan dari aktivitas rumah sakit atau fasilitas kesehatan lainnya sangat berbahaya dan dapat menimbulkan gangguan kesehatan bagi manusia. Salah satu cara pengolahan sampah medis yaitu dengan cara menggunakan insinerator. Penelitian ini bertujuan untuk mengetahui pengaruh tekanan blower pada proses insinerasi sampah medis terhadap kadar Kadmium (Cd), Kromium VI $\left(\mathrm{Cr}^{+6}\right)$, dan Timbal $(\mathrm{Pb})$ pada residu abu berdasarkan uji TCLP. Metode yang diterapkan yaitu menimbang sampah medis sebanyak $300 \mathrm{Kg}$ kemudian dibakar di insinerator dengan variasi tekanan blower 10 dan 30 mbar pada suhu optimal sebesar $1.200^{\circ} \mathrm{C}$. Hasil penelitian menunjukkan bahwa Uji TCLP kadar terbaik dengan tekanan blower 10 mbar yaitu Cd sebesar $0,411 \mathrm{mg} / \mathrm{L}$ pada percobaan $2, \mathrm{Cr}^{+6}$ sebesar $0,143 \mathrm{mg} / \mathrm{L}$ pada percobaan 2, dan $\mathrm{Pb}$ sebesar 59,4 mg/L pada percobaan 3. Sedangkan, hasil Uji TCLP kadar terbaik pada percobaan 3 dengan tekanan blower 30 mbar yaitu Cd sebesar $0,34 \mathrm{mg} / \mathrm{L}, \mathrm{Cr}^{+6}$ sebesar $0,098 \mathrm{mg} / \mathrm{L}$, dan $\mathrm{Pb}$ sebesar 42,2 mg/L. Hasil penelitian menunjukkan bahwa kadar $\mathrm{Cd}$ dan $\mathrm{Cr}^{+6}$ telah memenuhi baku mutu lingkungan sedangkan kadar $\mathrm{Pb}$ belum memenuhi baku mutu lingkungan yang disyaratkan.
\end{abstract}

Kata Kunci: insinerasi, sampah medis, uji TCLP, tekanan blower, rumah sakit

\section{Pendahuluan}

Rumah sakit merupakan institusi pelayanan kesehatan yang memberikan fasilitas pelayanan meliputi pelayanan rawat jalan, rawat inap, pelayanan gawat darurat, pelayanan medik, pelayanan penunjang medik, dan pelayanan non medis bagi perorangan [1]. Menurut Keputusan Menteri Kesehatan Republik Indonesia Nomor 1204 Tahun 2004 Tentang Persyaratan Kesehatan Lingkungan Rumah Sakit bahwa, rumah sakit menghasilkan berbagai macam limbah dari kegiatan pelayan medik maupun penunjang medik, baik limbah cair, padat, dan gas yang berpotensi menimbulkan gangguan kesehatan bagi manusia. Selain itu, limbah medis dapat mencemari dan membahayakan lingkungan hidup, serta kelangsungan hidup manusia dan makhluk hidup lainnya [3].

Limbah medis tergolong dalam Limbah Bahan Berbahaya dan Beracun (B3) dengan karakteristik infeksius [4]. Hal ini dikarenakan limbah medis mengandung berbagai jasad renik penyebab penyakit pada manusia termasuk demam typoid, kolera, disentri, dan hepatitis, sehingga limbah tersebut harus terlebih dahulu melewati proses pengelolaan limbah medis sesuai Peraturan Pemerintah Nomor 101 Tahun 2014 Tentang Pengelolaan Limbah B3 sebelum dibuang ke lingkungan [1]. Rumah sakit sebagai tempat penunjang layanan kesehatan wajib memperhatikan terkait sistem pengelolaan limbah medis agar pelayanan kesehatan lebih baik, nyaman, dan sehat seiring dengan meningkatnya kebutuhan masyarakat 
terhadap pelayanan kesehatan. Semakin bagus tipe rumah sakit maka semakin banyak volume limbah yang dihasilkan [6].

Salah satu cara untuk pengolahan limbah padat medis adalah menggunakan cara insinerasi dengan alat insinerator. Insinerator adalah alat pembakaran yang digunakan untuk membakar sampah yang menggunakan suhu tinggi, proses ini disebut insinerasi [7]. Insinerasi merupakan suatu proses pengolahan limbah padat baik umum maupun medis dengan proses pembakaran pada suhu $800-1.000^{\circ} \mathrm{C}$ untuk mengurangi volume sampah mudah terbakar (combustible) yang sudah tidak dapat didaur ulang lagi serta dapat membunuh virus, bakteri dan kimia toksik [8]. Pemilihan teknologi insinerasi yang bagus dapat menurunkan potensi pencemaran yang ditimbulkan oleh residu abu sisa pembakaran dan gas buang pembakaran [9]. Teknologi insinerasi merupakan teknologi yang banyak digunakan karena memiliki tingkat efisiensi dan efektivitas yang tinggi hingga 90\% untuk mengolah limbah medis menjadi abu [10].

Insinerator tipe statis banyak digunakan di berbagai rumah sakit karena sistem mengoperasionalkan yang mudah serta dapat mereduksi volume sampah hingga 99,9\% menjadi abu [11]. Tekanan blower yang besar akan mempengaruhi jumlah kebutuhan udara yang masuk [12]. Uji TCLP (Toxicity Characteristic Leaching Procedure) digunakan untuk mengevaluasi, mengetahui, dan mengurangi pengaruh pencemaran. Uji TCLP dilakukan untuk menentukan mobilitas zat organik dan anorganik yang terdapat dalam limbah atau residu seperti, Ag (Perak), As (Arsenik), B (Boron), Ba (Barium), Cd (Kadmium), $\mathrm{Cr}^{6+}$ (Kromium VI), Cu (Tembaga), Hg (Merkuri), Pb (Timbal), dan Zn (Seng) [13]. Berdasarkan uraian di atas, peneliti bertujuan melakukan penelitian menggunakan insinerator statis di RSUD Dr. Soetomo Surabaya untuk mengetahui pengaruh waktu dan tekanan blower terhadap kinerja insinerator dalam menganalisis kadar pencemar abu. Setelah melakukan pembakaran sampah medis dengan variasi waktu dan tekanan blower, maka dilakukan uji kadar logam untuk mengetahui kandungan toksisitas dari residu abu yaitu kadar $\mathrm{Cd}, \mathrm{Pb}$, dan $\mathrm{Cr}^{+6}$.

\section{Metode Penelitian Sampel Penelitian}

Sampel penelitian diambil langsung di RSUD Dr. Soetomo Surabaya setelah dilakukan pengumpulan dari beberapa sumber limbah. Sampel yang di teliti diambil dari sumber sampah medis dan menimbang sampah medis yang berasal dari troli sampah sebanyak $300 \mathrm{~kg}$. Jenis sampah medis yang akan dijadikan sampel penelitian digolongkan dalam beberapa penggolongan yang terdiri dari sampah medis A: alat suntik, jarum suntik, pisau dan gunting (45\%). Jenis sampah medis B: selang hemodialisis, alat kesehatan hemodialisis, botol infus (50\%). Jenis sampah medis C: baterai (5\%). Sampah medis yang telah di timbang kemudian dimasukkan ke dalam insinerator statis berkapasitas $2 \mathrm{~m}^{3}$ dengan mengatur suhu dengan batas maksimal $1.200 \mathrm{C}^{\circ}$, serta mengatur tekanan blower dengan tekanan 10 dan 30 mbar.

\section{Tahap Pengumpulan Data}

Pengumpulan data yakni dengan menggunakan cara uji TCLP pada residu abu dari proses pembakaran sampah medis menggunakan insinerator statis. Residu abu di ambil $1 / 2 \mathrm{~kg}$ (500 gram) dan di bawa ke laboratorium untuk dilakukan Uji TCLP. Parameter uji yang dijadikan dalam penelitian ini adalah $\mathrm{Cd}, \mathrm{Cr}^{6+}$, dan $\mathrm{Pb}$.

\section{Metode Analisi Data}

Setelah data terkumpul, data dianalisis berdasarkan golongannya. Data yang sudah dianalisis selanjutnya di tabulasikan dalam bentuk grafik dari setiap parameter, kemudian dideskripsikan berdasarkan golongannya. Metode grafik batang menjadi acuan dalam melihat hasil perubahan dari penelitian tersebut.

\section{Hasil dan Pembahasan \\ Efektifitas Penurunan Berat Sampah Medis}

Insinerator ini memiliki kemampuan reduksi volume yang besar dan juga cocok untuk memusnahkan berbagai jenis limbah. Dalam proses insinerasi memiliki kelebihan dan kekurangan dalam aspek kesehatan lingkungan [7]. Keuntungan dari pengolahan limbah dengan proses insinerasi yaitu proses insinerasi dapat mengurangi volume dan berat limbah secara signifikan, limbah dapat ditangani dalam waktu yang relatif singkat, luas area yang dibutuhkan tidak terlalu besar jika dibandingkan dengan Tempat Pemrosesan Akhir (TPA) [11]. Setelah dilakukan pembakaran pada 3 kali percobaan dengan bobot sampah medis awal sebanyak $300 \mathrm{~kg}$ diperoleh efektivitas pembakaran seperti pada Tabel 1. 


\begin{tabular}{cccc}
\multicolumn{3}{c}{ Tabel 1. Efektivitas penurunan berat sampah medis setelah proses pembakaran } \\
\hline Percobaan & Berat Awal Sampah & \multicolumn{2}{c}{ Variasi Tekanan Blower (Mbar) } \\
\cline { 3 - 4 } Ke- & Medis (Kg) & 10 & 30 \\
\hline 1 & 300 & $26,3 \mathrm{Kg}$ & $23,4 \mathrm{Kg}$ \\
2 & 300 & $27,1 \mathrm{Kg}$ & $22 \mathrm{Kg}$ \\
3 & 300 & $26,9 \mathrm{Kg}$ & $24,1 \mathrm{Kg}$ \\
\hline
\end{tabular}

Hasil akhir proses pembakaran sampah medis seperti yang tersaji pada Tabel 1 menunjukkan hasil yang cukup besar dalam mengurangi sampah medis. Pada tekanan blower $10 \mathrm{Mbar}$, penyisihan sampah medis terbanyak terjadi pada percobaan pertama yang mampu menghilangkan sampah medis sebanyak $273,7 \mathrm{Kg}$ dari berat sampah awal sampah yaitu $300 \mathrm{Kg}$. Sedangkan pada tekanan blower $30 \mathrm{Mbar}$ penurunan terbaik terjadi pada percobaan ke-2 yang mampu menghilangkan sampah medis hingga 278 Kg. Suhu dan waktu pembakaran sangat berpengaruh pada bobot akhir sampah medis yang dibakar. Kemampuan pembakaran incinerator rotary kiln termodifikasi dengan berat awal sampah $500 \mathrm{Kg}$ diperoleh hasil akhir pembakaran sebesar $21 \mathrm{Kg}$ atau tereduksi sebesar 96\% [14].

Analisis Data Kadar Kadmiun (Cd)

Cd merupakan logam berat yang memiliki toksisitas tinggi yang bersifat bioakumulatif, biomagnifikasi, toksik, dan karsinogenik yang dapat terakumulasi pada jaringan tubuh makhluk hidup [15]. Toksisitas Cd bisa merusak sistem fisiologis, respirasi, sirkulasi darah, reproduksi, syaraf, kerapuhan tulang, kerusakan ginjal, dan menurunkan fungsi pulmo dalam tubuh [16]. Berdasarkan uraian di atas, maka menurut Peraturan Pemerintah Nomor 101 Tahun 2014 baku mutu Cd pada residu abu insenerator maksimal yaitu $0,15 \mathrm{mg} / \mathrm{L}$. Analisis data kadar Cd dilakukan pada saat proses pembakaran sampah medis selesai. Percobaan 1, 2, dan 3 dengan menggunakan tekanan blower 30 mbar memperoleh hasil yang lebih kecil dengan rerata sebesar $0,427 \mathrm{mg} / \mathrm{L}$ dari pada tekanan blower 10 mbar dengan rerata sebesar 0,484 mg/L. Secara lengkap hasil uji TCLP kadar Cd pada percobaan 1, 2, dan 3, serta hasil rerata yang tersaji pada Gambar 1.

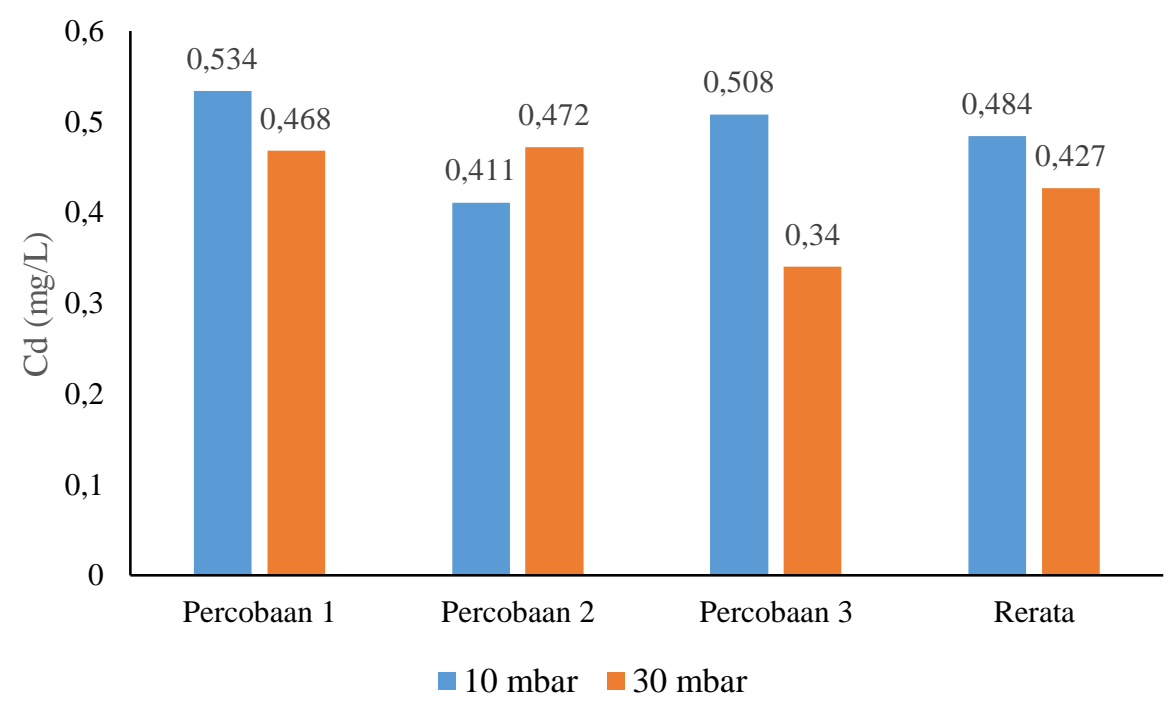

Gambar 1. Hasil uji TCLP Cd

Berdasarkan Gambar 1 dapat diketahui bahwa, hasil Uji TCLP kadar Cd menunjukkan hasil yang berbeda untuk setiap tekanan blower. Pada percobaan 3 dengan tekanan 30 mbar merupakan hasil uji TCLP Cd yang paling rendah yaitu sebesar $0,34 \mathrm{mg} / \mathrm{L}$, sedangkan pada percobaan 2 dengan tekanan 10 mbar merupakan hasil uji TCLP Cd yang paling rendah yaitu sebesar $0,411 \mathrm{mg} / \mathrm{L}$. Semakin rendah hasil uji TCLP Cd, maka hasil akan semakin baik bagi kesehatan lingkungan. Hasil uji TCLP Cd yang berbeda pada penelitian ini disebabkan karena lubang/output blower insinerator tertutup oleh residu abu pada saat proses insenerasi, sehingga tekanan udara dari blower tidak bisa optimal dalam menyuplai tungku pembakaran insinerator. Hasil penelitian yang berbeda menunjukkan bahwa, proses pembakaran boiler pada suhu $600-1.000^{\circ} \mathrm{C}$ menggunakan kombinasi bahan bakar batu bara dan Spent Bleaching Earth (limbah padat industri kelapa sawit) mampu menghasilkan abu residu dengan kadar Cd sebesar 0,9 mg/L [17]. 


\section{Analisis Data Kadar Kromium VI $\left(\mathrm{Cr}^{6+}\right)$}

Kromium VI $\left(\mathrm{Cr}^{6+}\right)$ merupakan logam berat yang memiliki toksisitas tinggi setelah yang bersifat bioakumulatif, biomagnifikasi, toksik, dan karsinogenik yang dapat terakumulasi pada jaringan tubuh makhluk hidup [15]. Toksisitas $\mathrm{Cr}^{6+}$ bisa merusak sistem fisiologis, respirasi, sirkulasi darah, reproduksi, syaraf, kerapuhan tulang, kerusakan ginjal, dan menurunkan fungsi pulmo dalam tubuh [16]. Berdasarkan uraian di atas, maka menurut Peraturan Pemerintah Nomor 101 Tahun 2014 baku mutu $\mathrm{Cr}^{6+}$ pada residu abu insenerator maksimal yaitu $2,5 \mathrm{mg} / \mathrm{L}$. Analisis data kadar $\mathrm{Cr}^{6+}$ dilakukan pada saat proses pembakaran sampah medis selesai. Percobaan 1, 2, dan 3 dengan menggunakan tekanan blower 30 mbar memperoleh hasil yang lebih kecil dengan rerata sebesar $0,101 \mathrm{mg} / \mathrm{L}$ dari pada tekanan blower $10 \mathrm{mbar}$ rerata sebesar 0,209 $\mathrm{mg} / \mathrm{L}$. Secara lengkap hasil uji TCLP kadar $\mathrm{Cr}^{6+}$ pada percobaan 1, 2, dan 3, serta hasil rerata yang tersaji pada Gambar 2.

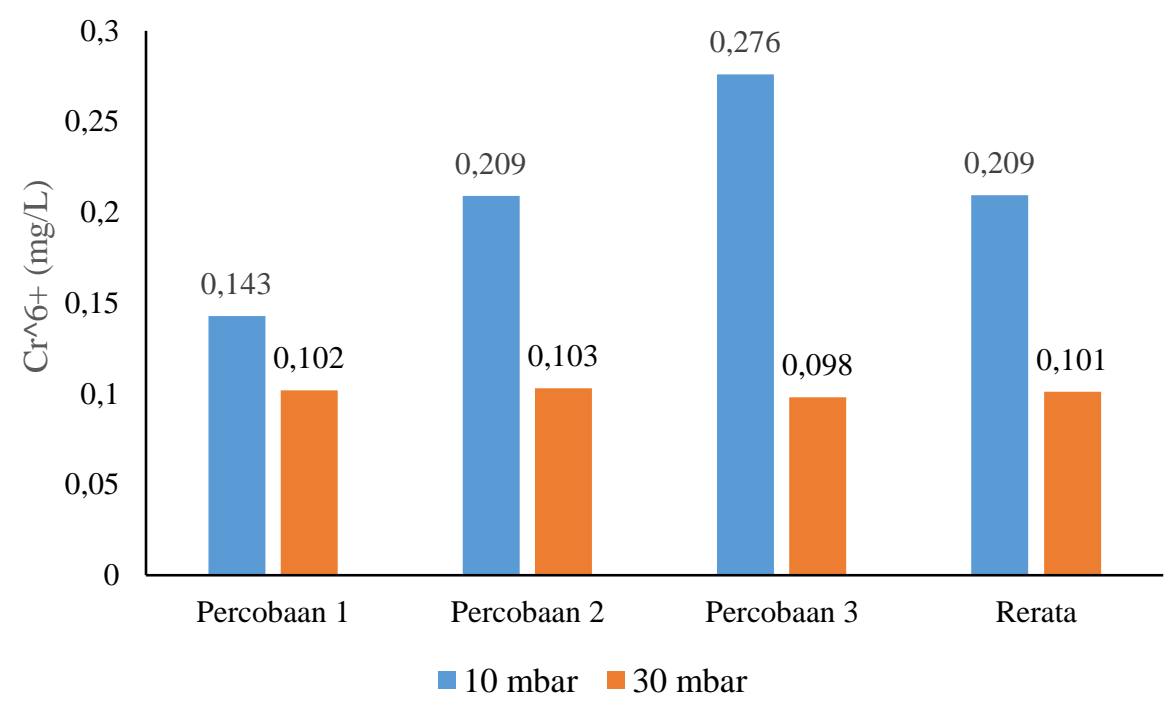

Gambar 2. Hasil uji TCLP Cr $\mathrm{Cr}^{6+}$

Pada Gambar 2 dapat diketahui bahwa, hasil Uji TCLP kadar $\mathrm{Cr}^{6+}$ menunjukkan hasil yang relatif stabil pada tekanan 30 mbar dan trendline kenaikan pada tekanan 10 mbar pada percobaan 1, 2, dan 3 . Pada percobaan 3 dengan tekanan 30 mbar merupakan hasil uji TCLP $\mathrm{Cr}^{6+}$ yang paling rendah yaitu sebesar $0,098 \mathrm{mg} / \mathrm{L}$, sedangkan pada percobaan 1 dengan tekanan 10 mbar merupakan hasil uji TCLP $\mathrm{Cr}^{6+}$ yang paling rendah yaitu sebesar $0,143 \mathrm{mg} / \mathrm{L}$. Semakin rendah hasil uji $\mathrm{TCLP} \mathrm{Cr}^{6+}$, maka hasil akan semakin baik bagi kesehatan lingkungan. Tekanan blower, waktu dan suhu pembakaran sangat berpengaruh besar terhadap hasil akhir penghilangan sampah medis. Hasil uji TCLP $\mathrm{Cr}^{6+}$ dengan tekanan 10 mbar yang mengalami trendline kenaikan pada penelitian ini disebabkan karena tekanan blower yang kurang optimal, sehingga suhu pada tungku pembakaran insinerator tidak bisa mencapai suhu optimal $1.200^{\circ} \mathrm{C}$. Penelitian terdahulu melaporkan bahwa, pembakaran limbah medis menggunakan Insinerator Statis di RSUD Dr. Soetomo Surabaya dengan tekanan blower $37 \mathrm{mbar}$, suhu $800-1.000{ }^{\circ} \mathrm{C}$, dan proses pembakaran selama 1 jam mampu menghasilkan abu residu dengan $\mathrm{kadar} \mathrm{Cr}^{6+}$ sebesar 0,003 mg/L [18]. Analisi Data Kadar Timbal (Pb)

Timbal $(\mathrm{Pb})$ merupakan salah satu logam berat yang sangat berbahaya bagi makhluk hidup karena bersifat karsinogenik, dapat menyebabkan mutasi genetika, terurai dalam jangka waktu lama, dan toksisitasnya tidak berubah [19]. Toksisitas $\mathrm{Pb}$ dapat menyebabkan penyakit kronis seperti kanker, gagal jantung, gagal ginjal, pengapuran tulang, dll [16]. Berdasarkan uraian di atas, maka menurut Peraturan Pemerintah Nomor 101 Tahun 2014 baku mutu Pb pada residu abu insenerator maksimal yaitu 0,5 mg/L. Analisis data kadar Cd dilakukan pada saat proses pembakaran sampah medis selesai. Percobaan 1, 2, dan 3 dengan menggunakan tekanan blower 30 mbar memperoleh hasil yang lebih kecil dengan rerata sebesar 48,233 mg/L dari pada tekanan blower $10 \mathrm{mbar}$ rerata sebesar 67,033 mg/L. Secara lengkap hasil uji TCLP kadar Pb pada percobaan 1, 2, dan 3, serta hasil rerata yang tersaji pada Gambar 3. 


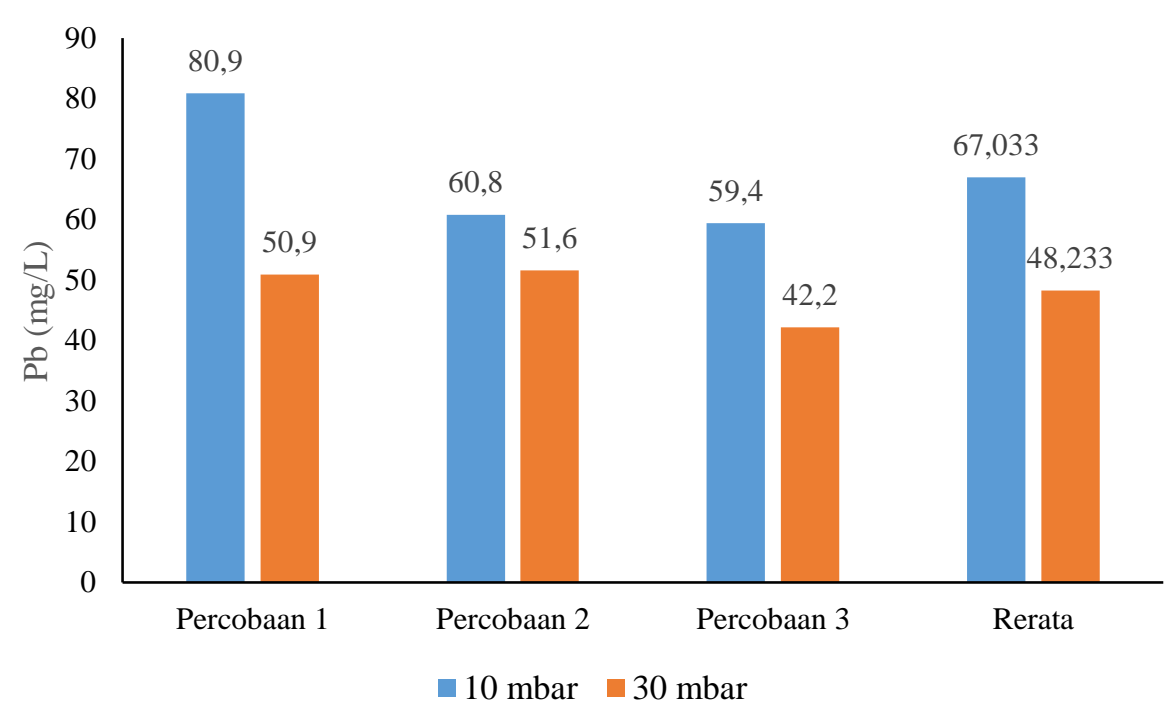

Gambar 3. Hasil uji TCLP Pb

Berdasarkan Gambar 3 dapat diketahui bahwa, hasil Uji TCLP kadar Pb menunjukkan hasil yang cukup signifikan untuk setiap variasi tekanan. Untuk kali ini pada percobaan 3 dengan tekanan 10 dan 30 mbar merupakan hasil uji TCLP Pb yang paling rendah dimana, pada tekanan 30 Mbar diperoleh hasil sebesar 42,2 mg/L, dan pada tekanan 10 mbar didapatkan hasil sebesar 59,4 mg/L. Hasil uji TCLP Pb masih jauh di atas baku mutu yang diprasyaratkan oleh Peraturan Pemerintah Nomor 101 Tahun 2014 yaitu $0,5 \mathrm{mg} / \mathrm{L}$, maka hasil ini dalam kategori berbahaya bagi kesehatan lingkungan dan makhluk hidup disekitar RSUD Dr. Soetomo Surabaya.

Hasil uji TCLP Pb yang berbeda pada tekanan 30 mbar disebabkan karena proses pembakaran belum mencapai tingkat maksimal akibat lubang/output blower insinerator tertutup oleh residu abu pada saat proses insenerasi, sehingga tekanan udara dari blower tidak bisa optimal dalam men yuplai tungku pembakaran insinerator. Penelitian terdahulu telah melaporkan bahwa, pembakaran limbah medis menggunakan Insinerator Statis di RSUD Dr. Soetomo Surabaya dengan tekan an blower $37 \mathrm{mbar}$, suhu $800-1.000{ }^{\circ} \mathrm{C}$, dan proses pembakaran selama 1 jam mampu menghasilkan abu residu dengan kadar $\mathrm{Pb}$ sebesar $0,0405 \mathrm{mg} / \mathrm{L}[18]$.

\section{Kesimpulan}

Pengaruh tekanan blower pada proses insinerasi sampah medis menjadi residu abu dengan proses pembakaran selama 1 jam diperoleh hasil uji TCLP kadar terbaik dengan tekanan blower 10 bar yaitu Cd sebesar $0,411 \mathrm{mg} / \mathrm{L}$ pada percobaan $2, \mathrm{Cr}^{+6}$ sebesar $0,143 \mathrm{mg} / \mathrm{L}$ pada percobaan 2, dan $\mathrm{Pb}$ sebesar 59,4 $\mathrm{mg} / \mathrm{L}$ pada percobaan 3. Sedangkan, hasil uji TCLP kadar terbaik pada percobaan 3 dengan tekanan blower 30 mbar yaitu Cd sebesar 0,34 mg/L, Cr ${ }^{+6}$ sebesar 0,098 mg/L, dan Pb sebesar 42,2 mg/L.

\section{Ucapan Terima Kasih}

Penulis mengucapkan terima kasih kepada RSUD Dr. Soetomo Surabaya yang telah memfasilitasi penelitian ini dan tim sanitarian RSUD Dr. Soetomo Surabaya yang telah banyak membantu dan memberikan support selama proses penelitian. Kemudian, penulis juga mengucapkan terima kasih kepada Dinas Lingkungan Hidup Kabupaten Mojokerto sebagai instansi penganalisa residu abu insinerator pada penelitian ini.

\section{Referensi}

[1] E. A. Noor, "Pertanggung Jawaban Rumah Sakit Terhadap Limbah Bahan Beracun Berbahaya (B3)," J. Penegakan Huk. Indones., vol. 1, no. 1, 2020.

[2] Kementerian Kesehatan Republik Indonesia, Keputusan Menteri Kesehatan Republik Indonesia Nomor 1204 Tahun 2004 Tentang Persyaratan Kesehatan Lingkungan Rumah Sakit. Indonesia, 2004.

[3] Y. Ruslinda and R. N. Permadi, "Timbulan, Komposisi dan Karakteristik Sampah Bahan Berbahaya dan Beracun (B3) pada Sarana Kesehatan,” J. Dampak, vol. 15, no. 2, pp. 59-64, 2018.

[4] USEPA, "Medical Waste.” 2011. 
[5] Pemerintah Pusat Republik Indonesia, Peraturan Pemerintah Nomor 101 Tahun 2014 Tentang Pengelolaan Limbah Bahan Berbahaya dan Beracun. Indonesia, 2014.

[6] A. A. Kerubun, "Kualitas Limbah Cair di Rumah Sakit Umum Daerah Tulehu," Media Kesehat. Masy. Indones., vol. 10, no. 3, pp. 180-185, 2014.

[7] S. N. Achmad, R. A. Nugroho, I. Mardliyah, and N. Oktavia, "Rancang Bangun Insinerator Limbah Medis Berteknologi Plasma sebagai Filter Udara Hasil Pembakaran Limbah Medis," in Prosiding Industrial Research Workshop and National Seminar, 2017, vol. 8, pp. 575-579.

[8] A. S. Latief, "Manfaat dan Dampak Penggunaan Insinerator Terhadap Lingkungan," J. Tek. Mesin Politek. Negeri Semarang, vol. 5, no. 1, pp. 20-24, 2010.

[9] E. Naryono, A. Rachmansyah, and S. Soemarno, "Perancangan Insinerator Fixed Bed Updraft Terintegrasi dengan Scrubber untuk Memisahkan Tar," SENTIA 2016, vol. 8, no. 2, 2016.

[10] V. E. Girsang and W. Herumurti, "Evaluasi Pengelolaan Limbah Padat B3 Hasil Insinerasi di RSUD Dr Soetomo Surabaya," J. Tek. ITS, vol. 2, no. 2, pp. D46-D50, 2013.

[11] A. M. Rizal and I. Nurhayati, "Pengolahan Limbah Bahan Berbahaya dan Beracun (B3) dengan Insinerator Tipe Reciprocating Grate Incinerator," WAKTU J. Tek. UNIPA, vol. 15, no. 2, pp. 2127, 2017.

[12] A. Desiarista, "Optimalisasi Waktu dan Suhu Pembakaran Untuk Peningkatan Kinerja Insinerator Sampah Medis," J. Purifikasi, vol. 19, no. 1, pp. 1-8, 2019.

[13] I. D. W. S. Rini, A. Gunawan, and A. I. Arobi, "Pengujian Logam Berat pada Tanah Terkontaminasi Air Limbah PLTD di Petung, Kalimantan Timur," SPECTA J. Technol., vol. 2, no. 2, pp. 19-26, 2018.

[14] R. D. Utami, D. G. Okayadnya, and M. Mirwan, "Meningkatkan Kinerja Incenerator pada Pemusnahan Limbah Medis RSUD Dr. Soetomo Surabaya," J. Ilm. Tek. Lingkung., vol. 7, no. 2, 2016.

[15] A. Sasongko, K. Yulianto, and D. Sarastri, "Verifikasi Metode Penentuan Logam Kadmium (Cd) dalam Air Limbah Domestik Dengan Metode Spektrofotometri Serapan Atom," JST (Jurnal Sains dan Teknol., vol. 6, no. 2, pp. 228-237, 2017.

[16] W. Widowati, A. Sastiono, and R. Jusuf, Efek Toksik Logam. Jakarta: Andi, 2008.

[17] L. Siami, D. Indrawati, T. Tazkiaturrizki, R. A. K. Dewi, and A. Dwiana, "Potensi Limbah B3 Spent Blaching Earth sebagai Bahan Bakar pada Industri Minyak Goreng PT. ABC," J. Penelit. DAN KARYA Ilm. Lemb. Penelit. Univ. TRISAKTI, vol. 6, no. 1, pp. 9-16, 2021.

[18] A. A. Purwanti, "Pengelolaan Limbah Padat Bahan Berbahaya dan Beracun (B3) Rumah Sakit di RSUD Dr. Soetomo Surabaya,” J. Kesehat. Lingkung., vol. 10, no. 3, pp. 291-298, 2018.

[19] M. H. Istiqomah, "Pemanfaatan Tulang Ikan Bandeng (Chanos Chanos) sbagai Media Biofilter dengan Penambahan Zeolit untuk Menurunkan Kadar Logam Berat Timbal (Pb)." UIN Sunan Ampel Surabaya, 2021. 